\title{
Applying Social Network Analysis to Build Social Mapping for Social Risk Management
}

\author{
Yoyok Hendarso ${ }^{1}$, Maulana Ali², Alamsyah ${ }^{3}$ \\ (yoyok_hendarso60@yahoo.co.id ${ }^{1}$,maulana@unitaspalembang.ac.id², alamsyah78@fisip.unsri.ac.id ${ }^{3}$ ) \\ ${ }^{1}$ Department of Sociology, Sriwijaya University, Jl. Raya Palembang-Prabumulih Km. 32 \\ Indralaya OI, Sumatera Selatan 30662, Indonesia \\ ${ }^{2}$ Postgraduate Department, Universitas Tamansiswa Palembang, Jl. Tamansiswa No. 261 \\ Palembang Sumatera Selatan 30126, Indonesia \\ ${ }^{3}$ Department of Public Administration, Sriwijaya University, J1. Raya Palembang-Prabumulih \\ Km. 32 Indralaya OI, Sumatera Selatan 30662, Indonesia
}

\begin{abstract}
Every corporation has social risks, including oil and gas corporations in South Sumatra Province. Social risk management efforts begin with creating social maps that illustrate the dynamics of social change in the community. Unlike the map of the physical environment which is relatively difficult to change, both in the short and long term, social maps are very adaptive to change. So far, oil and gas corporations in South Sumatra rely more on the PRA/RRA method in implementing social mapping. Even though the PRA/RRA method is still the best for expressing the aspirations of the downstream at the grassroots level, it is incompetent to reveal the network of actors at the community level. Drawing on from empirical research in Petaling and Danau Cala Village, Lais Sub-district, Musi Banyuasin District, South Sumatera Province, Indonesia, this article would like to show the strength of the SNA method as a tool in social mapping.
\end{abstract}

Keywords: Social Network, Social Mapping, Social Risk Management.

\section{Introduction}

The orientation of economic development in fisheries sector is an effort to the sustainability Conflict over natural resource management does not only occur in South Sumatra Province but occurs in many regions, for example manganese mining in South East Timor District [1] (Usboko, 2016, pp. 1-21), gold in Bombana Regency [2] (Amri, 2013, pp. 59 -70), iron sand in Kulon Progo Regency [3] (Astuti, 2012, pp. 62-74), and water [4],[5] (Pomeroy et al., 2007, pp. 645-656; Strauß, 2011, pp. 69-79). Resource conflicts also occur in renewable natural resource management sectors, such as forests [6] (Barber, 1998, pp. 4-9), oil palm plantations [7],[8] (Obidzinski, Andriani, Komardin, \& Andrianto, 2012; Rist, Feintrenie, \& Levang, 2010), and fish [9] (Muawanah, Pomeroy, \& Marlessy, 2012, pp. 279288). Although the causes and impacts of each conflict are very contextual, 'local factors' are the key to understand social conflict in Indonesia [10] (Barron, Kaiser, \& Pradhan, 2009, pp. 698-713).

One way that corporations often use to understand 'local factors' is the method of Participatory Rural Appraisal / PRA [11]-[15] (Chambers, 1994a, pp. 1253-1268, 1994b, pp. 953-969; Leurs, 1996, pp. 57-72; Mosse , 1994, pp. 497-526; Webber \& Ison, 1995, pp. 107- 
131) and Rapid Rural Appraisal / RRAS [16],[17] (Chambers, 1981, pp. 95-106; Wood, 1981, pp. 3-7) which were integrated with a Corporate Social Responsibility / CSR approach [18],[19],[20] (Cadbury, 2006, pp. 5-21; McWilliams, 2015, pp. 1-4; Muchlinski, 2008, pp. 161-188). Because of its participatory character, PRA / RRA has the power to explore valid and reliable information from a particular group of citizens or communities. However, unlike the other data collection techniques in the social sciences, PRA / RRAS ignores the fact that a group of people who are PRA / RRAS participants are in an interconnected social environment, not an independent subject. PRA / RRAS does allow participants to argue and discuss based on their daily life experiences. However, this participatory process does not yet integrate network perspectives that emphasize the importance of building network data (relational data) to understand the dynamics of social networks of groups of individuals (individuals or groups) in a particular social environment as developed by the Social Network Analysis (SNA) approach.

This article adopts the SNA approach to explain the social network of residents of Petaling Village and Danau Cala Village, Lais District, Musi Banyuasin Regency, South Sumatra Province. Article is focused on answering a number of questions, namely: what are the characteristics of social networks in Petaling Village and Danau Cala Village? Who are the dominant actors in social networks in Petaling Village and Danau Cala Village? How many factions are there in social networks in Petaling Village and Danau Cala Village? What are the practical implications of the research findings for the efforts of oil and gas corporate communications operating in the two villages that were the location of the research? What are the theoretical implications of this research finding for further research on social mapping?

\section{Social Network Analysis (SNA)}

Social network analysis (SNA) is the process of investigating social structures through the use of networks and graph theory [21]. It characterizes networked structures in terms of nodes (individual actors, people, or things within the network) and the ties, edges, or links (relationships or interactions) that connect them. Examples of social structures commonly visualized through social network analysis include social media networks [22], memes spread [23], information circulation [24], friendship and acquaintance networks, business networks, social networks, collaboration graphs, kinship, disease transmission, and sexual relationships [25], [26]. These networks are often visualized through sociograms in which nodes are represented as points and ties are represented as lines.

Social network analysis has emerged as a key technique in modern sociology. It has also gained a significant following in anthropology, biology, demography, communication studies, economics, geography, history, information science, organizational studies, political science, social psychology, development studies, sociolinguistics, and computer science and is now commonly available as a consumer tool (see the list of SNA software) [27], [28]. 


\section{Method}

This study uses a quantitative-descriptive approach, specifically the method of social network analysis [29] (Wasserman \& Faust, 1994). The research location is in Petaling Village and Danau Cala Village, Lais District, Musi Banyuasin Regency, South Sumatra Province. Sources of data came from 19 villagers who were chosen by snowball techniques. The first informant interviewed was one of the villagers who served as village officials. The structured interview process is guided by a special questionnaire prepared in advance. Data were analyzed by UCINET application [30] (Borgatti, Everett, \& Freeman, 2002) and focused on explaining the structural attributes of social networks (for example, network density, reciprocity, transitivy, degree neutrality, betweenness, closeness, core-periphery, and clique) in Petaling and Danau Cala village.

\section{Results}

\subsection{Social Network at Petaling Village}

Figure 1 visualizes the social network patterns of the Petaling villagers produced by the UCINET software. This network has 38 (thirty eight) actors (nodes), 216 ties, and a density score of 0.706 . This density figure indicates that the bonds formed in the network have reached 70 percent. There are still 30 percent of ties that might occur in the network. This network includes solid. From the total of these 216 ties, everything is reciprocal ( $a$ to $b$ and $b$ to a). Because reciprocal is stable for a long time, it is often used as a measure of network stability. A 100 percent reciprocal number can be considered high reciprocity.

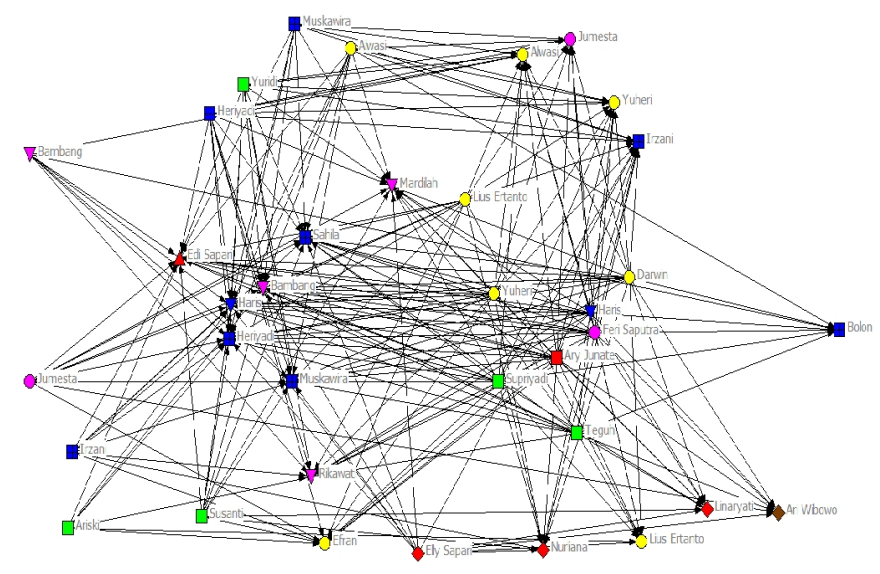

Fig.1. Social Network of Residents of Petaling Village

If reciprocal measures the reciprocal relationship between two actors (dyad), then reciprocal relations between the three actors are explained by transitivity. This network transitivity score reaches 0.772 . It means, there are 77 percent of ties between actors in this network involving three people and fulfilling the principle of transitivity (if $a$ to $b, b$ to $a$, then 
a to c). Transitivity is also an indicator of network stability and consistency. The transitivity rate of 77 percent shows network stability and consistency in the high category.

Who are the influential actors in this network? There are three indicators that can be used to answer this question. First, the Freeman Degree Centrality score, specifically the score nOutdeg (sending ties or naming names) and nIndeg (accepting the bond or name referred to). From the score of nOutdeg, the actors who send the most ties (mentioning the names of other actors) are Fery Saputra (1.000, youth organizations), Haris (1.000, village secretaries), Ary Junate (0.941, teachers), Darwin (0.941, BPD), Supriyadi (0.882, villagers), Yuheri (0.882, BPD), and Lius Ertanto (0.824, BPD). Whereas the actors who receive ties from other people or the names most often referred to by other actors are Feri Saputra (1.000, youth organizations), Haris (1.000, village secretaries), Ary Junate (0.941, teachers), Darwin (0.941, BPD), Lius Ertanto (0.824, BPD), Supriyadi (0.882, villagers), and Yuheri (0.882, BPD). From nIndeg score, there were two dominant actors in this network, namely Haris and Feri Saputra, because they had nIndeg score of 1.000 which indicated the influence of both in the social network of the Petaling population of 100 percent or the total network area. This fact is not surprising because Haris's identity as a village secretary has full responsibility for managing the internal problems of the village administration. Whereas Feri Saputra is one of the active youth club administrators.

\subsection{Social Network at Danau Cala Village}

Figure 2 visualizes the social network patterns of the residents of Danau Cala Village produced by the UCINET software. This network has 40 (forty) actors, 130 ties, and a density score of 0.342 . This density figure indicates that the bonds formed in the network only reached 34 percent. There are still 66 percent of bonds that might occur in the network.

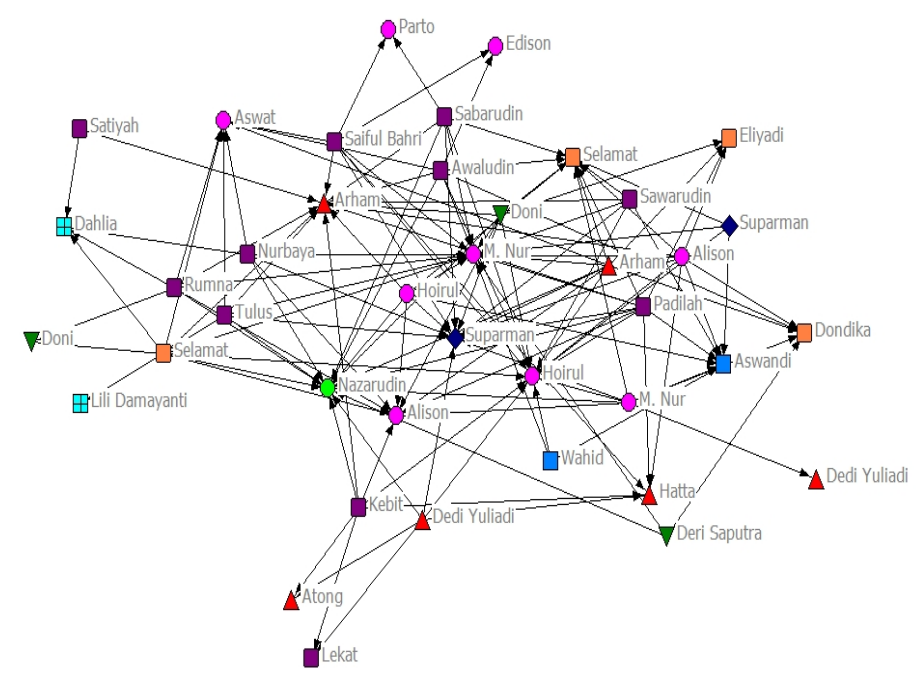

Fig.2. The Social Network Pattern of the Residents of Danau Cala Village 
Legend

Status

Head of Hamle

PKK

BPD

Head of village
Symbol

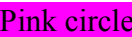

Light blue

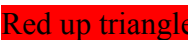

Light green circle

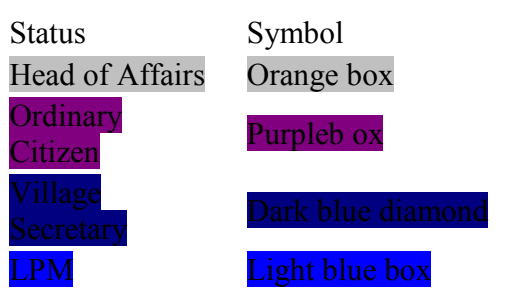

From the total of 130 ties, there are 42 (forty two) reciprocal bonds ( $a$ to $b$ and $b$ to a) or 32 percent and 88 (eighty eight) bonds that are not reciprocal. Because reciprocal is stable for a long time, it is often used as a measure of network stability. Reciprocal numbers of 32 percent (under 50 percent) can be considered low reciprocal. This network is unstable, unequal, but tends to be hierarchical. This is actually very surprising. Because, almost all informants knew each other.

If reciprocal measures the reciprocal relationship between two actors (dyad), then reciprocal relations between the three actors are explained by transitivity, this network transitivity score reaches 0.503 . This shows that 50 percent of ties between actors in the network involve three people and fulfill the principle of transitivity ( $a$ to $b, b$ to $a$, then $a$ to $c$ ). Transitivity is also an indicator of network stability and consistency. The 50 percent transitivity rate indicates network stability and consistency in the medium category.

Who are the influential actors in this network? There are three indicators that can be used to answer this question. First, we can use the Freeman Degree Centrality score. This method produces several actors that are central to networking because the name is called by someone else or receives a bond from someone else. They are Selamat (0.789), Suparman (0.737), Arham (0.684), Saiful Bahri (0.684), Tulus (0.526), Wahid (0.632). Selamat is the most influential figure in this network because he can affect 78 percent of the network area.

\section{Discussion}

This research was designed to map the pattern of social relations between government officials and villagers in Petaling Village and Danau Cala Village. Starting from the social relations data collected from 19 (nineteen) residents of Petaling Village and Danau Cala Village, this research concluded, first, social networks in Petaling Village are cohesive (solid), stable, equal, not hierarchical, tend to be consistent, and have 16 factions. Villagers who carry out the role of elite village government (village secretaries, youth organizations, teachers and BPD) tend to play a central role in networking. There are six names that influence the social networks in Petaling, namely Feri Saputra (youth organization), Haris (village secretary), Ary Junate (teacher), Darwin (BPD), Lius Ertanto (BPD), Supriyadi (villagers), and Yuheri (BPD). The four highest-ranking actors who have overlapping social relations are Haris (village secretary), Heriyadi (head of hamlet), and Bambang (head of affairs).

Secondly, social networks in Danau Cala Village are not dense, unstable, unequal, and tend to be hierarchical, but tend to be consistent and have 45 factions. Villagers who play the role of elite village government (village secretary, head of hamlet, head of affairs, BPD chairman / member, LPM member) tend to play a central role in networking. The only ordinary villager who has a central role in the social network of the residents of Danau Cala 
Village is Syaiful Bahri. There are three actors who sent something in the process of social exchange at the network level, namely Arham (0.633), Awaludin (0.633), Padilah (0.633) whereas actors who will receive something faster than other actors in the process of social exchange at the network level are Selamat (0.826), Suparman (0.792), Syaiful Bahri (0.760), and Arham (0.633). The informants included in the core group were Alison (head of hamlet), Arham (BPD chairman), Awaludin (ordinary citizen), Dedi Yuliadi (BPD member), Saiful Bahri (ordinary citizen), Selamat (head of affairs), Suparman (village secretary), Tulus (ordinary citizen), Wahid (LPM member). While the actors included in the periphery category are Deri Saputra (youth organization), Doni (youth organization), Hoirul (head of hamlet), Kebit (ordinary citizens), M. Nur (head of hamlet), Nurbaya (ordinary citizens), Padilah (ordinary citizens), Rumna (ordinary citizen), Sabarudin (ordinary citizen), Satiyah (ordinary citizen), Sawarudin (ordinary citizen). There are four actors who have the most social relations connected with the clique, namely Arham (head of the BPD), M. Nur (head of hamlet), Nazarudin (village head), and Suparman (village secretary).

\section{Conclusion}

Based on the findings above, the researchers recommend that the village government elites, both in Petaling Village and Danau Cala Village, be used as accesspoints to establish communication with residents. In Petaling Village, because social networking is stable, efforts to manage CSR programs and social risks in Petaling Village will be easier. In the Danau Cala village, because social networking is not stable, it is necessary to systematically stabilize networks through activities that can increase the social capital of the residents of Danau Cala Village. This finding reinforces the SNA method as a quantitative approach that is able to visualize and explain the structural attributes of social networks. However, because this research is only quantitative-descriptive, it cannot test the strength of the causal relationship between actor attributes (eg gender, education level, income level) with network structural variables (for example, centrality, betweenness, closeness, and so on). In the future, in order to be able to predict and test hypotheses, inferential SNA methods, for example the Exponential Random Graph Modeling (ERGM) technique (Harris, 2014), need to be considered as a tool to analyze social networks.

Acknowledgments. This research was funded by Medco Energy, Ltd., based on contract number XXX/SSE/MEDC/VIII/2017.

\section{References}

[1] I. Usboko, "Role Players Analysis dalam Konflik Pengelolaan Sumber Daya Alam," Politika: Jurnal Ilmu Politik, vol. 7, no. 1, pp. 1-21, 2016, available from: https://doi.org/https://doi.org/10.14710/politika,7,1,16-36.

[2] U. Amri, "Power Contestation and Environmental Degradation: Evidence from Bombana’s Gold Mining Site, Southeast Sulawesi Province, Indonesia," Politika: Jurnal Ilmu Politik, vol. 1, no. 2, pp. 59-70, 2013, available from https://doi.org/http://dx.doi.org/10.14710/politika.1.2.2010.59-70.

[3] E.Z.L. Astuti, "Konflik Pasir Besi: Pro dan Kontra Rencana Penambangan Pasir Besi di Kabupaten Kulon Progo," Jurnal Ilmu Sosial Dan Ilmu Politik, vol. 16, no. 1, pp. 62-74, 2012, available from https://doi.org/https://doi.org/10.22146/jsp.10912.

[4] R. Pomeroy, J. Parks, R. Pollnac, T. Campson, E. Genio, C. Marlessy, and N. Thu Hue, "Fish Wars: Conflict and Collaboration in Fisheries Management in Southeast Asia," 
Marine Policy, vol. 31, no. 6, pp. 645-656, 2007, available from https://doi.org/10.1016/j.marpol.2007.03.012.

[5] S. Strauß, "Water Conflicts among Different User Groups in South Bali, Indonesia," Human Ecology, vol. 39, no.1, pp. 69-79, 2011, avalable from https://doi.org/10.1007/s10745-011-9381-3

[6] C.V. Barber, "Forest Resource Scarcity \& Social Conflict in Indonesia," Environment: Science and Policy for Sustainable Development, vol. 40, no. 4, pp. 4-9, 1998, available from https://doi.org/10.1080/00139159809604579

[7] K. Obidzinski, R. Andriani, H. Komardin, and A. Andrianto, "Environmental and Social Impacts of Oil Palm Plantations and Their Implications for Biofuel Production in Indonesia," Ecoogy and Society, vol. 17, no. 1, pp. 25-45, 2012, available from https://doi.org/http://dx.doi.org/10.5751/ES-04775-170125

[8] L. Rist, L. Feintrenie, and P. Levang, "The Livelihood Impacts of Oil Palm: Smallholders in Indonesia," Biodiversity and Conservation, vol. 19, no. 4, pp. 1009 1024, 2010, available from https://doi.org/10.1007/s10531-010-9815-z

[9] U. Muawanah, R.S. Pomeroy, and C. Marlessy, "Revisiting Fish Wars: Conflict and Collaboration Over Fisheries in Indonesia," Coastal Management, vol. 40, no. 3, pp. 279-288, 2012, available from https://doi.org/10.1080/08920753.2012.677633

[10] P. Barron, K. Kaiser, and M. Pradhan, "Understanding Variations in Local Conflict: Evidence and Implications from Indonesia.," World Development, vol. 37, no. 3, pp.698713, 2009, available from https://doi.org/10.1016/j.worlddev.2008.08.007

[11] R. Chambers, "Participatory Rural Appraisal (PRA): Analysis of Experience," World Development, vol. 22, no. 9, pp. 1253-1268, 1994a, available from https://doi.org/10.1016/0305-750X(94)90003-5

[12] R. Chambers, "The Origins and Practice of Participatory Rural Appraisal," World Development, vol. 22, no. 7, pp.953-969, 1994b, available from https://doi.org/10.1016/0305-750X(94)90141-4

[13] R. Leurs, "Current Challenges Facing Participatory Rural Appraisal," Public Administration and Development, vol. 16, no. 1, pp. 57-72, 1996, available from https://doi.org/10.1002/(SICI)1099-162X(199602)16:1<57::AID-PAD853>3.0.CO;2-Z

[14] D. Mosse, "Authority, Gender and Knowledge: Theoretical Reflections on the Practice of Participatory Rural Appraisal,” Development and Change, vol. 25, no. 3, pp. 497-526, 1994, available from https://doi.org/10.1111/j.1467-7660.1994.tb00524.x

[15] L.M. Webber and R.L. Ison, "Participatory Rural Appraisal Design: Conceptual and Process Issues," Agricultural Systems, vol. 47, no. 1, pp. 107-131, 1995, available from https://doi.org/10.1016/0308-521X(94)P3278-3

[16] R. Chambers, "Rapid Rural Appraisal: Rationale and Repertoire," Public Administration and Development, vol.1, no.2, pp. 95-106, 1981, available from https://doi.org/10.1002/pad.4230010202

[17] G.D. Wood, "The Social and Scientific Context of Rapid Rural Appraisal," The IDS Bulletin, vol.12, no.4, pp.3-7, 1981, available from https://doi.org/10.1111/j.17595436.1981.mp12004002.x

[18] A. Cadbury, "Corporate Social Responsibility," Twenty-First Century Society, vol. 1, no. 1, pp. 5-21, 2006, available from https://doi.org/10.1080/17450140600679883

[19] A. McWilliams, "Corporate Social Responsibility," In Wiley Encyclopedia of Management, Chichester, Ed. UK: John Wiley \& Sons, Ltd, 2015, pp. 1-4. available from https://doi.org/10.1002/9781118785317.weom120001

[20] P. Muchlinski, “Corporate Social Responsibility," in The Oxford Handbooks of 
International Investment Law, P. Muchlinski, F. Ortino, and C. Schreuer, Eds. Oxford University Press: Oxford University Press, 2008, available from https://doi.org/10.1093/oxfordhb/9780199231386.013.0017

[21] E. Otte and R. Rousseau, "Social Network Analysis: A Powerful Strategy, also for the Information Sciences," Journal of Information Science, vol. 28, no. 6, pp. 441-453, 2002.

[22] M. Grandjean, "A Social Network Analysis of Twitter: Mapping the Digital Humanities Community," Cogent Arts \& Humanities, vol. 3, no. 1, 2016.

[23] H.R. Nasrinpour, M.R. Friesen, and R.D. McLeod, (2016-11-22), "An Agent-Based Model of Message Propagation in the Facebook Electronic Social Network", 2016, available from https://arxiv.org/abs/1611.07454

[24] M. Grandjean, "Complex Structures and International Organizations [Analisi e visualizzazioni delle reti in storia. L'esempio della cooperazione intellettuale della Società delle Nazioni]," Memoria e Ricerca, no.2, pp. 371-393, 2017.

[25] C.A.R. Pinheiro, Social Network Analysis in Telecommunications. Hoboken, NY: John Wiley \& Sons, p.4, 2011.

[26] A. D'Andrea, et al., "An Overview of Methods for Virtual Social Network Analysis," in Computational Social Network Analysis: Trends, Tools and Research Advances, A. Abraham, Ed. New York, NY: Springer. p. 8, 2009.

[27] L. Frederic, "Wolfram Alpha Launches Personal Analytics Reports for Facebook," Tech Crunch, 2012.

[28] M. Ivaldi, L. Ferreri, F. Daolio, M. Giacobini, M. Tomassini, and A. Rainoldi, "WeSport: From Academy Spin-Off to Data-Base for Complex Network Analysis; An innovative Approach to a New Technology," J Sports Med and Phys Fitnes, vol. 51, suppl. 1, no. 3.

[29] S. Wasserman and K. Faust, Social Network Analysis: Method and Applications. Cambridge, UK: Cambridge University Press, 1994.

[30] S.P. Borgatti, M.G. Everett, and L.C. Freeman, UCINET for Windows: Software for Social Network Analysis. Massachusetts, USA: Analytic Technologies, 2002. 